\title{
Hair Cell Death in the Avian Basilar Papilla: Characterization of the in vitro Model and Caspase Activation
}

\author{
Alan G. Cheng, Lisa L. Cunningham, and Edwin W Rubel \\ Virginia Merrill Bloedel Hearing Research Center, Department of Otolaryngology-Head and Neck Surgery, \\ University of Washington, Seattle, WA 98195, USA
}

Received: 11 April 2002; Accepted: 13 July 2002; Online publication: 7 November 2002

\section{ABSTRACT}

Caspases are a family of proteases that have been implicated as key mediators of cell death. Although nonspecific inhibition of caspase activation has been reported to prevent mammalian sensory hair cell death, the exact roles of individual caspases during hair cell death are unclear. In other systems, the activation of initiator caspases, such as caspase- 8 and caspase-9, can lead to the activation of the effector caspase-3. We have begun to systematically characterize hair cell death in an in vitro system by examining the activation of these specific caspases in degenerating hair cells after acutely damaging the whole avian basilar papilla with gentamicin. Basilar papillae (BP) displayed a dose-dependent hair cell loss after a 24-h treatment with gentamicin at concentrations of $0.1,0.5$, and $2.0 \mathrm{mM}$. When treated with $0.5 \mathrm{mM}$ gentamicin for 6,12 , or $24 \mathrm{~h}$, hair cells first began to degenerate in the basal third of the BP and damage progressed apically. Supplementation of z-VAD-fmk, a general caspase inhibitor, provided short-term protection against gentamicin-induced hair cell death. Treatment with gentamicin for 6 or 12 $\mathrm{h}$ promoted the expression of active caspase- 3 and active caspase- 9 in many hair cells along the BP as shown by immunohistochemistry. At these timepoints, specific fluorescent-labeled peptide substrates detected more active caspase- 3 , caspase- 8 , and caspase-9 in gentamicin-treated hair cells relative to

Correspondence to: Edwin W Rubel • Virginia Merrill Bloedel Hearing Research Center - Box 357923 - University of Washington. Telephone: (206) 543-8360; fax: (206) 221-5685; email: rubel@ u.washington.edu controls. Our data indicate that auditory hair cells degenerate as a result of gentamicin exposure in a caspase-dependent manner. Specifically, the upstream caspases, caspase- 8 and caspase- 9 , and the downstream caspase- 3 are activated in aminoglycoside-damaged hair cells.

Keywords: hair cell death, gentamicin, aminoglycoside, caspase, basilar papilla

\section{INTRODUCTION}

Sensory hair cells are susceptible to damage under numerous conditions such as excessive noise, aging, and exposure to certain classes of therapeutic drugs including the aminoglycosides. The mechanisms of hair cell death as a result of these diverse stresses appear to be similar and share many of the characteristics of programmed cell death (apoptosis; Forge 1985; Li et al. 1995; Lang and Liu 1997; Usami et al. 1997; Zheng et al. 1998; Lenoir et al. 1999; Forge and Li 2000; Hu et al. 2000; Pirvola et al. 2000; Matsui et al. 2002). Hair cells dying in an apoptotic-like manner participate in an active, organized cellular degradation and disposal with preserved tissue integrity and minimal inflammatory response (Li et al. 1995; Lang and Liu 1997; Forge and Li 2000). Such preservation of the architecture of the sensory epithelium (SE) is crucial in order to retain organ function, particularly in tissues where hair cells are continuously produced throughout life (Weisleder and Rubel 1993; Kil et al. 1997; Williams and Holder 2000). 
Apoptotic cells are characterized by their stereotypical morphologic changes, including chromatin condensation and margination, cytoplasmic condensation, and formation of apoptotic bodies (Kerr et al. 1972; Clarke and Clarke 1995). On a molecular level, DNA fragmentation, as a result of activated endonucleases and degraded DNA repair enzymes, is a hallmark of apoptosis (Gavrieli et al. 1992). After exposure to aminoglycosides, dying hair cells show these morphologic changes in vitro (Li et al. 1995; Lang and Liu 1997; Forge and Li 2000; Matsui et al. 2002) and in vivo (Forge 1985; Lenoir et al. 1999). Apoptotic nuclear changes following aminoglycoside treatment have been observed in the vestibular and auditory organs in mammals and birds (Forge 1985; Li et al. 1995; Lang and Liu 1997; Lenoir et al. 1999; Torchinsky et al. 1999; Forge and Li 2000; Matsui et al. 2002).

Cellular stresses, such as ultraviolet light, toxins, and neurotrophin withdrawal, can be translated into cell death signals and thus can activate the apoptotic machinery (for reviews, see Earnshaw et al. 1999; Slee et al. 1999a). If these cell death signals overwhelm survival factors (e.g., bcl-2), they activate a family of cell death mediators termed caspases. Caspases comprise a unique family of cysteine-dependent, aspartate-specific proteases that normally exist as inactive zymogens (pro-caspases; for reviews, see Earnshaw et al. 1999 and Nicholson 1999). Several genes involved in apoptosis, including that of caspase-3 (ced-3), were first described in the nematode C. elegans (Yuan et al. 1993). Caspases are widely conserved through evolution and are found in multicellular organisms from worms to mammals (Earnshaw et al. 1999). Caspases recognize specific tetrapeptide sequences and cleave protein elements including their own prodomains. Cleavage of the prodomain activates the caspase. Activated caspases dismantle components of the cytoskeleton (Mashima et al. 1995, 1997; Janicke et al. 1998) and nuclear scaffolds (Lazebnik et al. 1995; Casiano et al. 1996). Fourteen caspase members have thus far been identified, with those mediating cell death falling into two general categories (Earnshaw et al. 1999; Nicholson 1999): initiators (caspase-8 and caspase-9) and effectors (caspase-3, caspase-6, and caspase-7). At least 70 individual substrates of caspases have thus far been identified (Nicholson 1999). Other caspase-mediated events include disabling DNA repair enzymes (Casiano et al. 1996) and activating DNA endonuclease (Enari et al. 1998; Tang and Kidd 1998). In addition to cellular digestion, caspases target and inactivate bcl- $\mathrm{X}_{\mathrm{L}}$, a member of the survival-promoting bcl-2 family (Clem et al. 1998). Perhaps most importantly, caspases cleave and activate other caspases, creating a positive feedback loop (Earnshaw et al. 1999; Nicholson 1999).
Compared with other organ systems, the roles of caspases in the overall cascade of cellular events leading to inner ear cell death have received relatively little attention. Liu et al. (1998) used a nonspecific caspase inhibitor to protect rat auditory hair cells from cisplatin-induced death in vitro. More recently, aminoglycoside-induced hair cell death has been shown to be caspase-mediated in the vestibular organs from mammals (Forge and Li 2000; Cunningham et al. 2002) and birds (Matsui et al. 2002). Individual caspases have not been described in the context of hair cell degeneration. It will prove essential for preventing cell death of the inner ear sensory elements to understand cell death and cell survival cascades as completely as possible. This report characterizes in vitro model of gentamicin-induced hair cell death in the avian hearing organ, the basilar papilla. Using this model, we have examined the effects of caspase inhibition on hair cell survival as well as the activation of specific caspases in gentamicin-treated hair cells.

\section{METHODS}

\section{Animals}

White Leghorn chicken (Gallus domesticus) eggs were obtained from a local distributor (H\&N International, Redmond, WA). These eggs were hatched in incubators and hatchlings were housed in brooders with food and water in the University of Washington animal care facility. All experimental protocols were reviewed and approved by the University of Washington Institutional Animal Care Committee and conform to NIH guidelines.

\section{Organ culture techniques}

Five- to 10-day-old hatchlings were rapidly decapitated and the basilar papillae (BP) were exposed, removed, and cultured as previously described (Oesterle et al. 1993). Under sterile conditions each BP was cultured as a whole, free-floating organ with an intact tegmentum vasculosum. One BP was placed in $700 \mu \mathrm{L}$ culture medium in individual wells of a 48-well tissue culture plate. Culture medium was composed of $66.7 \%$ Basal Medium Eagle (Sigma, St. Louis, MO), 33.3\% Earle's balanced salt solution (EBSS) (Gibco/ BRL, Gaithersburg, MD), and 5\% fetal bovine serum (Gibco/BRL). Cultured whole organs were incubated at $37^{\circ} \mathrm{C}$ in a $5 \% \mathrm{CO}_{2}$ atmosphere in a Forma Scientific (Marietta, $\mathrm{OH}$ ) incubator.

\section{Experimental paradigms}

Whole organ BPs were cultured for 18-24 h before any pharmacologic manipulations. Gentamicin (Sig- 
ma) was stored as a $20 \mathrm{mM}$ stock solution and diluted in culture medium immediately before application. A general caspase inhibitor, z-VAD-fmk (Enzyme Systems, Livermore, CA), and its inactive structural analog z-FA-fmk (BD Biosciences Pharmingen, San Diego, CA), were both stored as $40 \mathrm{mM}$ solutions in DMSO (Sigma) and prepared shortly before use. A subset of the cultures was preincubated with z-VADfmk or z-FA-fmk for $2 \mathrm{~h}$ before gentamicin was added (Forge and $\mathrm{Li} 2000$ ) to ensure adequate cellular penetration of the agents. The viability of hair cells in cultured BPs treated with z-VAD-fmk alone showed no obvious difference from that of untreated, cultured BPs.

Tissues were exposed to $0.1,0.5$, or $2.0 \mathrm{mM}$ gentamicin for $24 \mathrm{~h}$ for dose-response measurements. The $0.5 \mathrm{mM}$ gentamicin dose was chosen for the remainder of the experiments including those examining the time course of hair cell death $(6,12$, and $24 \mathrm{~h}$ ). Tissues were fixed immediately at the end of each culture period by immersion in buffered $4 \%$ paraformaldehyde in $0.1 \mathrm{M} \mathrm{Na}^{+} / \mathrm{K}^{+}$phosphate buffer ( $\mathrm{pH}$ 7.4) for 30-60 min at room temperature (RT) and rinsed in $0.1 \mathrm{M}$ phosphate-buffered saline (PBS).

\section{Immunohistochemistry}

Oregon green- and rhodamine-conjugated phalloidin were obtained from Molecular Probes (Eugene, OR). Primary antibodies directed against cleaved (activated) caspase-3 (dilution 1:200) and caspase-9 (dilution 1:100) were obtained from R\&D Systems (Minneapolis, MN) and Cell Signaling (Beverly, MA), respectively. Dr. Anthony Frankfurter (University of Virginia) generously donated the monoclonal Tuj1 antibody (dilution 1:1000).

At the end of the culture periods, organs were fixed and the tegmentum vasculosum and tectorial membrane were dissected free. Hair cells were either stained with anti-Tuj1 or phalloidin. Oregon greenor rhodamine-phalloidin diluted $1: 100$ in $0.05 \%$ Triton X-100/PBS (Sigma) was applied to tissues at RT for $2 \mathrm{~h}$. When anti-Tuj1 was used as a hair cell marker (Stone et al. 1996), tissues were first blocked with $10 \%$ normal goat serum (Sigma) in $0.05 \%$ Triton $\mathrm{X}-100 / \mathrm{PBS}$ for $30 \mathrm{~min}$ before being bathed in antiTuj 1 at $4^{\circ} \mathrm{C}$ overnight. The same histological protocol was followed for the use of other primary antibodies at the dilutions indicated above. Further immunolabeling was done using BODIPY, Alexa 488, or Alexa 594 conjugated to IgG (Molecular Probes) as secondary antibodies, diluted at 1:200 in block solution at RT for $2 \mathrm{~h}$. Organs were mounted onto slides using Vectashield mounting medium (Vector Laboratory, Burlingame, CA) and coverslipped.

\section{Caspase substrates}

The fluorogenic substrates (Intergen, Purchase, NY) consist of short peptide consensus sequences conjugated to a fluorescent probe. They specifically recognize and irreversibly bind the active sites of individual activated caspases (Bedner et al. 2000). These substrates were prepared as $150 \mathrm{x}$ stock solutions in sterile PBS and stored at $-20^{\circ} \mathrm{C}$. Fam-VAD-fmk substrate $(10 \mu \mathrm{M})$ was used to detect general caspase activity, fam-DEVD-fmk substrate ( $5 \mu \mathrm{M})$ was used for caspase3 activity, fam-LEHD-fmk substrate $(5 \mu \mathrm{M})$ was used to detect caspase-9 activity, and fam-LETD-fmk substrate $(5 \mu \mathrm{M})$ was used to detect caspase- 8 activity. These substrates were diluted shortly before being directly applied to the culture medium for $1 \mathrm{~h}$ at the end of the culture periods. After the $1 \mathrm{~h}$ incubation, tissues were washed with buffer (Intergen) and fixed with buffered $10 \%$ formalin (Intergen) at $4^{\circ} \mathrm{C}$ overnight.

\section{Data analysis}

Hair cell quantification in whole mount BPs. Tissue analysis consisted of three steps: First, tissues were examined under a Zeiss Axiophot epifluorescent microscope with a $10 x$ objective. Several digital images were taken using Object-Image (NIH) to cover the entire sensory epithelium (SE). A manual z-series of images was collected to account for the convex surface of the SE. Adobe Photoshop (Adobe Systems, San Jose, CA) was then used to montage all of the digital images captured from a single BP. In the second step of the analysis, the SE was manually outlined and bisected longitudinally from the apex to base. This step allowed the computer to create 10 boxes at equal intervals perpendicular to the longitudinal axis of the BP. The computer computes the orientation of the longitudinal axis at any point by averaging the curvature of the surrounding $10 \%$ length of the cochlea. Each box had a width exactly equal to $2 \%$ of the axial length of the BP and was divided into superior and inferior segments. Figure 1 shows a montage image of an untreated BP cultured for 2 days with the 10 boxes and a midline drawn over it.

Finally, a single experimenter counted the number of hair cells within the segments of each box. A hair cell was included in the counts if it was brightly labeled with phalloidin and at least partially located within a box. Because gentamicin-damaged hair cells might lack stereocilia bundles, controls using a specific hair cell marker, Tuj1, were performed to ensure that loss of phalloidin staining accurately reflected hair cell loss (see below). Boxes containing overtly mechanically damaged SE or poor imagery were discarded. This was less than $1 \%$ of the sampled areas. Hair cell density was calculated as hair cells per 100 


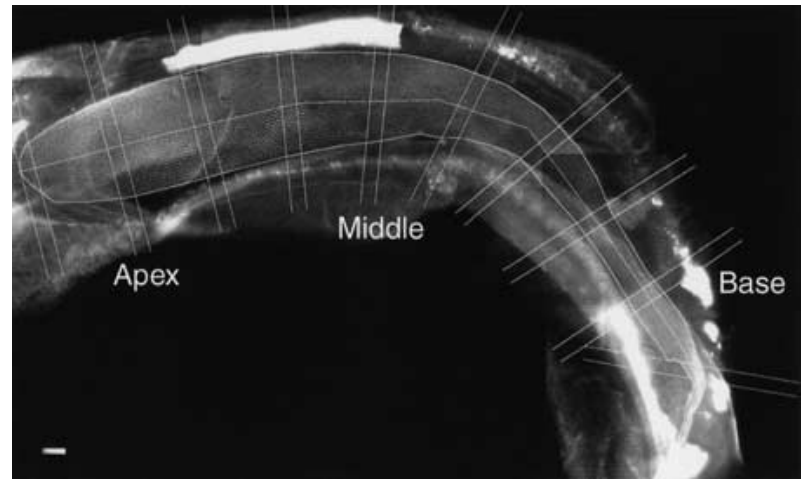

FIG. 1. Method of quantification. Whole-organ basilar papillae (BP) from posthatch 5- to 10-day-old chicks were incubated in culture media supplemented with 5 fetal bovine serum and then fixed and labeled with phalloidin. A montage of the sensory epithelium (SE) was constructed under low power. The SE was then outlined, and a line was drawn from apex to base along the middle of the SE. The computer then constructed 10 boxes at equal intervals perpendicular to the longitudinal axis of the BP. Because the computer estimates the longitudinal axis by averaging the curvature of the surrounding 10 length along the cochlea, boxes in greatly curved areas (e.g., boxes 6 and 10) might not appear completely perpendicular to the line drawn manually. The width of each box equals 2 of the axial length of the BP. Hair cell density was calculated in each box along the length of the BP to assess hair cell survival (see Materials and Methods). Scale bar $=100 \mu \mathrm{m}$.

$\mu \mathrm{m} \times 100 \mu \mathrm{m}\left(10,000 \mu \mathrm{m}^{2}\right)$. Analysis of variance (ANOVA) was followed by appropriate individual comparisons used for statistical calculations; $p<0.05$ was considered statistically significant.

To ensure the reproducibility of this method, 10 random BPs (3 controls, 3 exposed to gentamicin for $12 \mathrm{~h}, 2$ exposed to gentamicin for $24 \mathrm{~h}$, and 2 exposed to gentamicin and z-VAD-fmk for $24 \mathrm{~h}$ ) were chosen by a second investigator. The original experimenter, now blinded to the treatment groups, repeated the hair cell counts. The correlation coefficient $(r)$ relating the two hair cell counts was 0.94 .

A separate control was done to ensure that loss of phalloidin staining was indicative of hair cell loss. Four BPs (2 controls and 2 exposed to $0.5 \mathrm{mM}$ gentamicin for $6 \mathrm{~h}$ ) were double-labeled with anti-Tuj1 and phalloidin. The number of cells stained with antiTuj1, but not phalloidin, was then estimated from these tissues. Of the total number of hair cells directly examined through double-labeling ( 3000), 0.26\% were Tuj1-positive and phalloidin-negative, whereas $1.66 \%$ were Tuj1-negative and phalloidin-positive.

Quantification of cells labeled for active caspase-3 and active caspase-9. Whole mount BPs were assessed using a confocal microscope with a 40x objective. The total numbers of double-labeled (Tuj1+ and active caspase$3+$ or active caspase- $9+$ ) and single-labeled (active caspase-3+ or active caspase-9+ only) hair cells were counted in each BP. Student's t-test was used to assess statistical significance of the difference between treatment groups.

\section{RESULTS}

\section{Dose- and time-dependent hair cell death}

In comparison with culture-free organs, there was a significant decline $(p<0.001)$ in overall hair cell density of untreated, cultured BPs after 2 days in vitro. In normal (culture-free) BPs the mean $( \pm$ SEM) hair cell densities were $695( \pm 36), 855( \pm 14)$, and 386 $( \pm 34)$ hair cells per $10,000 \mu \mathrm{m}^{2}$ for the apical, middle, and basal thirds, respectively. The corresponding densities after 18-24 h in culture were $449( \pm 76), 458$ $( \pm 57)$, and $164( \pm 17)$, respectively. This represents an overall hair density of about $55 \%$, similar to the data reported by Frenz et al. (1998). This drop in hair cell density can be attributed to spreading of the sensory epithelium in vitro and hair cell death as a result of explantation and being placed in the culture system. After the initial 18-24 h of culture, hair cell densities stabilized as BPs cultured for 2 and 3 days showed no statistical difference in their hair cell densities (data not shown).

Hair cell survival decreased as the concentration of gentamicin increased in the culture media. Figure 2 shows the relationship between gentamicin concentration and hair cell survival. At each of the three doses of gentamicin tested, hair cell density was the lowest in the basal region and increased in a gradient fashion toward the apex. In addition, a decline in the overall hair cell density was noted throughout the BP as the concentration of gentamicin increased from $0.1(n=4)$ to $0.5(n=14)$ to $2.0 \mathrm{mM}(n=4)$. A significant interaction between the concentration of gentamicin and hair cell densities along the BP was observed ( $p<0.001$; two-way ANOVA). Tissues treated with any dose of gentamicin had significantly lower $(p<0.001)$ hair cell densities than the controls $(n=10)$.

The influence of aminoglycoside exposure time at a single gentamicin concentration $(0.5 \mathrm{mM})$ is demonstrated in Figure 3. This figure shows the hair cell densities, grouped according to their location along the BP, of gentamicin-treated BPs normalized to their parallel cultured controls. In comparison to parallel control cultures, drug-treated tissues displayed progressively lower hair cell density as the duration of gentamicin exposure increased. No significant change in hair cell density in the basal region was observed between the 12- and 24-h treatment paradigms. Meanwhile the basal-apical gradient of hair cell densities was retained at all time-points. There was a significant interaction between time of exposure to $0.5 \mathrm{mM}$ gentamicin and hair cell densities along the 


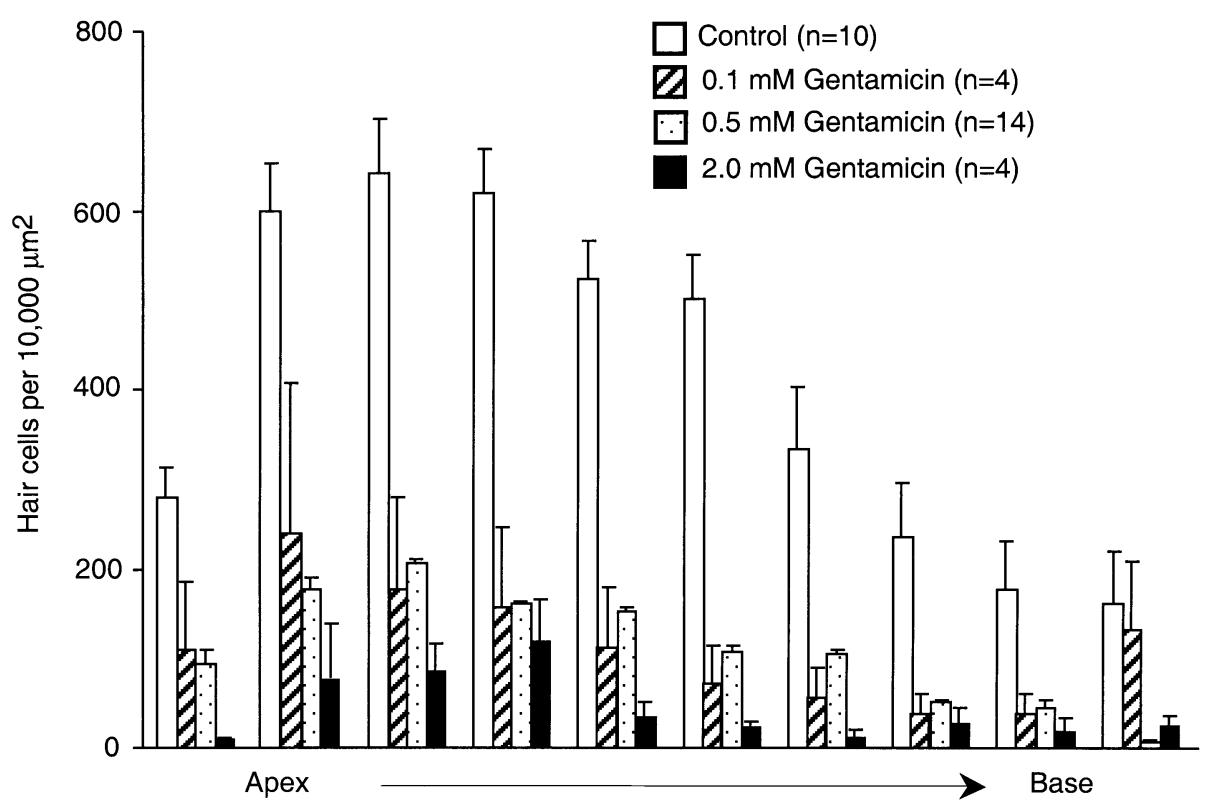

FIG. 2. Relationship between gentamicin dose and hair cell survival along the length of the basilar papilla (BP). Organotypic cultures were incubated in antibiotic-free media for 1 day before exposure to 0 (control), $0.1,0.5$, or $2.0 \mathrm{mM}$ gentamicin for $24 \mathrm{~h}$. Treatment with any of the tested doses significantly lowered $(p<0.001)$ hair cell

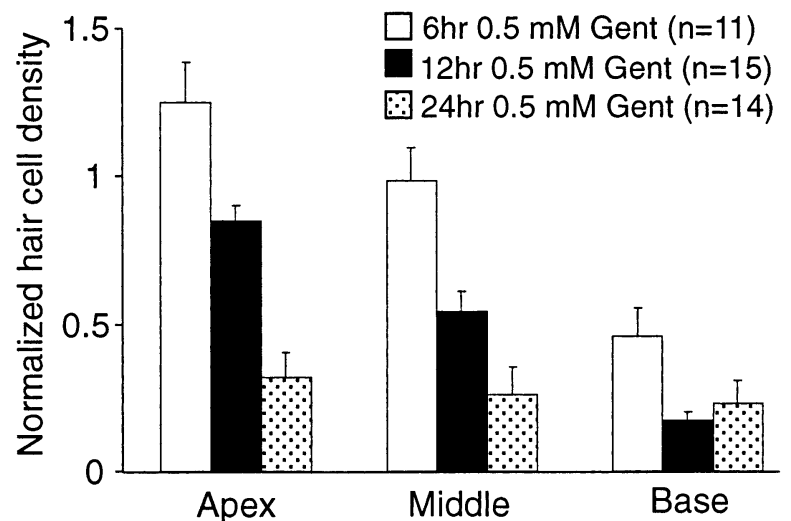

FIG. 3. Hair cell survival decreased in a time-dependent manner after $0.5 \mathrm{mM}$ gentamicin treatment. Hair cell densities along the basilar papilla (BP) were divided into apical (3 apical boxes in Fig. 1), middle (3 middle boxes), and basal thirds (4 basal boxes). Hair cell densities from gentamicin-treated BPs were then normalized to those of parallel untreated, cultured BPs according to their location on the BP (apical, middle, or basal). The density of apical hair cells from BPs treated with gentamicin for $6 \mathrm{~h}$ is not statistically different from that of controls. Basal hair cell loss was readily apparent as early as $6 \mathrm{~h}$ after gentamicin exposure. Both the middle and basal thirds demonstrated decreased hair cell survival after aminoglycoside treatment for $12 \mathrm{~h}$. At this time-point, the hair cell density in the apical region remained comparable to that of controls. By $24 \mathrm{~h}$ of gentamicin exposure, over 60 of hair cells throughout the BP had degenerated. Using two-way ANOVA, we found a significant main effect of exposure time $(p<0.001)$ and a significant interaction between exposure time to gentamicin and hair cell position along the BP $(p<0.001)$. Error bars $=$ SEM.

BP $(p<0.001$; two-way ANOVA). Notable hair cell loss was first detected in the basal third of the BP after $6 \mathrm{~h}$ density along the BP relative to controls. In addition, at the doses used, the apical-basal gradient of hair cell density was blunted with gentamicin treatment. There was a significant interaction between the concentration of gentamicin and hair cell position along the BP $(p<0.001 ;$ two-way ANOVA). Error bars = SEM.

of exposure to gentamicin $(n=11)$ in comparison to untreated BPs $(n=7)$. After $12 \mathrm{~h}$ of gentamicin exposure, a significant drop in hair cell density was observed in both the middle and basal thirds of the BP $(n=15, p<0.001)$. At the end of a 24-h treatment period, gentamicin-exposed BPs had significantly lower $(n=14, p<0.001)$ hair cell densities $(<35 \%$ of controls) along the entire length of the BP. Figure 4 shows representative photomicrographs of the untreated, control BPs (Fig. 4A-C) and those treated with $0.5 \mathrm{mM}$ gentamicin for 12 hours (Fig. 4D-F).

\section{Caspase inhibition}

z-VAD-fmk, a broad-spectrum caspase inhibitor, works by irreversibly binding the active sites on caspases, thus quenching the caspase activity. When z-VAD-fmk $(100 \mu \mathrm{M})$ was applied along with gentamicin to BPs, hair cell integrity was promoted at both $12(n=4)$ and $24 \mathrm{~h}(n=6)$ of gentamicin exposure. This increase in hair cell survival was significant at both 12 and $24 \mathrm{~h}(p<0.001)$. Hair cell densities of BPs treated with gentamicin and z-VAD-fmk for $12 \mathrm{~h}$ is not statistically different from that of untreated, cultured control organs (data not shown). Table 1 shows hair cell densities of drug-treated BPs normalized to their respective controls according to the location along the BP (apical, middle, basal). An additional negative control experiment using $100 \mu \mathrm{M}$ z-FA-fmk, an inactive analog of z-VAD-fmk, and $0.5 \mathrm{mM}$ gentamicin showed no increased hair cell survival with respect to 


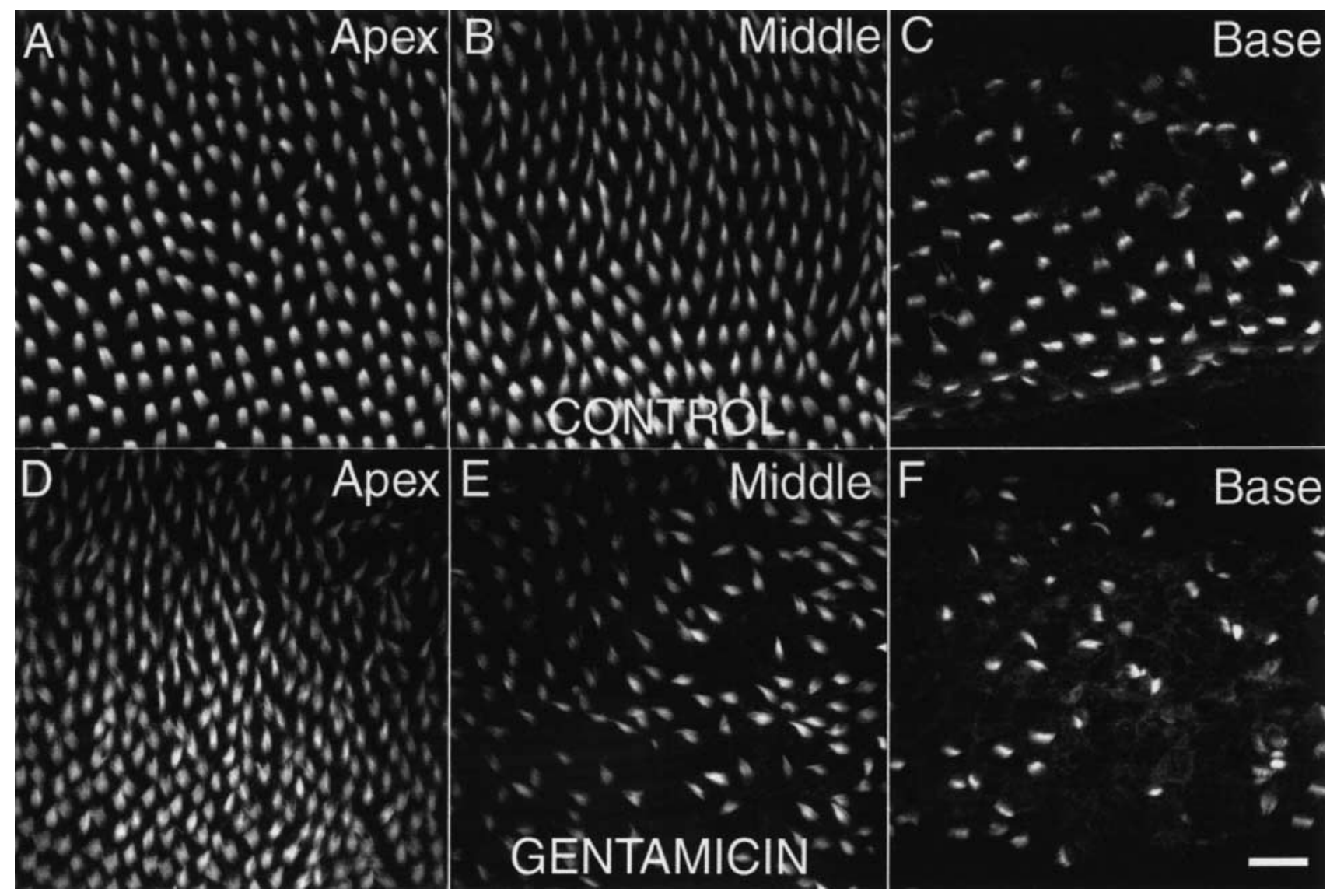

FIG. 4. Representative examples of cultured whole-organ basilar papillae (BP) stained with fluorescent-conjugated phalloidin. Thirtysix hours in culture. A-C. Untreated control BPs showing apical, middle, and basal segments. Note a dense population of hair cells with some loss in the basal region. D-F. Gentamicin-treated BPs: treatment with $0.5 \mathrm{mM}$ gentamicin for $12 \mathrm{~h}$ after $24 \mathrm{~h}$ in control media. There is noticeable hair cell loss in the middle and basal thirds of the BP. The hair cell density in the apical region is similar to that of control BPs. Scale bar $=20 \mu \mathrm{m}$.

\section{TABLE 1}

Effects of nonspecific caspase inhibition on hair cell survival ${ }^{a}$

\begin{tabular}{|c|c|c|c|c|}
\hline & Treatment duration (h) & Apex & Middle & Base \\
\hline Gentamicin $^{b}$ alone & 12 & $0.85 \pm 0.05$ & $0.54 \pm 0.07$ & $0.17 \pm 0.03$ \\
\hline Gentamicin $^{b}+$ z-VAD-fmk ${ }^{c}$ & 12 & $1.28 \pm 0.10$ & $0.96 \pm 0.09$ & $1.15 \pm 0.25$ \\
\hline Gentamicin $^{b}$ alone & 24 & $0.32 \pm 0.08$ & $0.37 \pm 0.10$ & $0.31 \pm 0.08$ \\
\hline Gentamicin $^{b}+z-V A D-f m k^{c}$ & 24 & $0.59 \pm 0.09$ & $0.48 \pm 0.11$ & $0.42 \pm 0.07$ \\
\hline
\end{tabular}

${ }^{a}$ Hair cell density normalized to control cultures \pm SEM.

${ }^{b}$ Gentamicin diluted to $0.5 \mathrm{mM}$ in all treatments.

${ }^{c} \mathrm{z}$-VAD-fmk $(100 \mu \mathrm{M})$, a general caspase inhibitor, was applied for $2 \mathrm{~h}$ and then along with gentamicin for the specified duration.

gentamicin treatment alone $(n=4$; data not shown). Despite concurrent treatment with caspase inhibitors and gentamicin, there was some decline in hair cell density from 12 to $24 \mathrm{~h}(p<0.001)$.

While it is possible for $\mathrm{z}$-VAD-fmk to have prevented hair cell death resulting from the culture environment, we expect this effect to be minimal for 2 reasons: (1) little general caspase activation was detected in the untreated, cultured BPs with the famVAD-fmk fluorogenic substrates and (2) hair cell densities of BPs cultured for 2 and 3 days are not statistically different.

\section{Immunolabeling for active caspases}

To begin studying hair cells in the process of degeneration, we used immunochemical detection of activated caspases in control basilar papillae and those treated for 6 or $12 \mathrm{~h}$ with gentamicin $(0.5 \mathrm{mM})$. Cultures were also double-labeled with an antibody to 


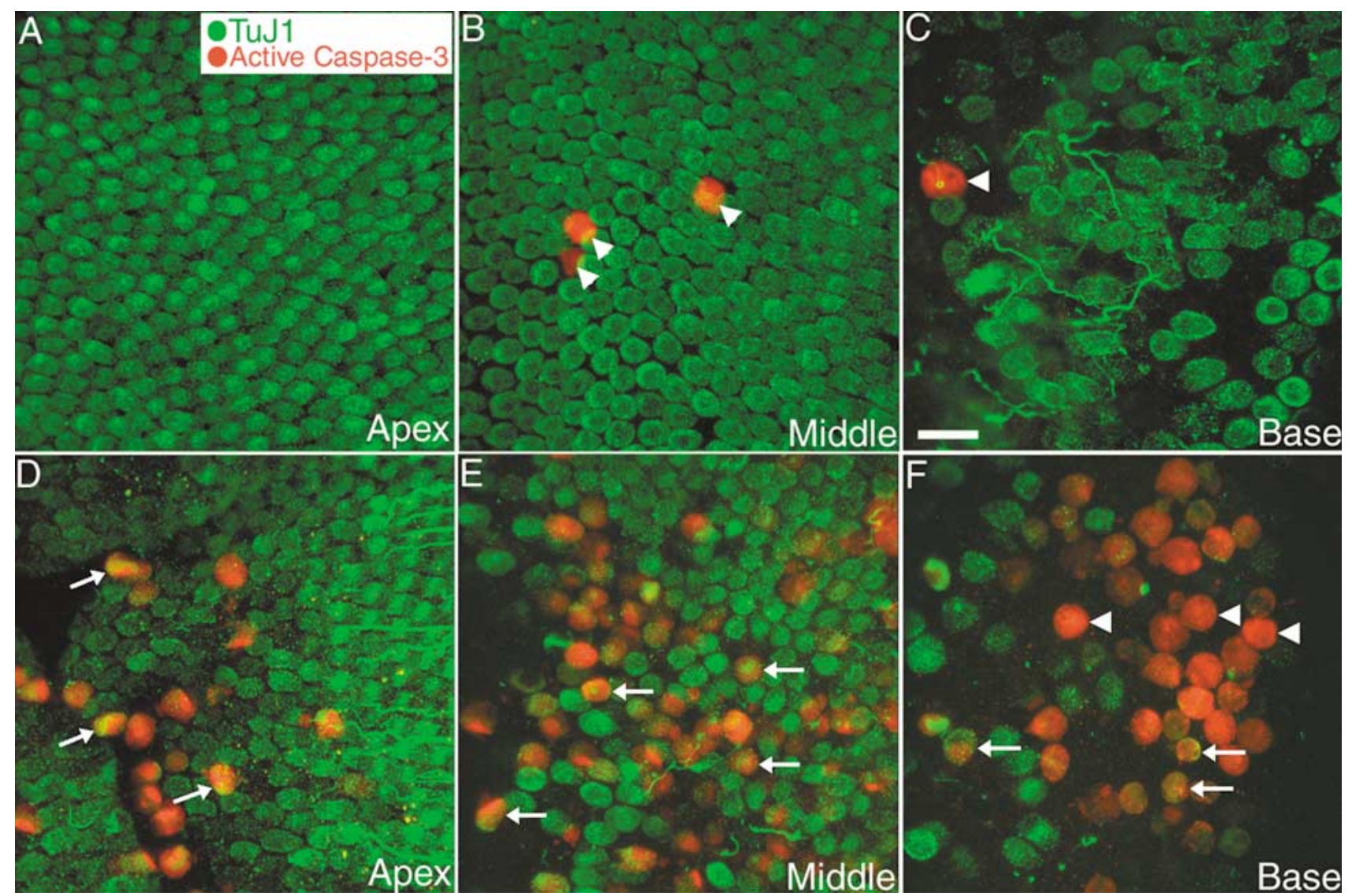

FIG. 5. Confocal images showing expression of active caspase-3 in hair cells from control and gentamicin-treated basilar papillae (BP). BPs were labeled for B-tubulin with anti-Tuj1 (green), a specific marker for chick inner ear hair cells and neurons, and anti-active caspase-3 (red). A-C. Untreated cultured BPs. Few hair cells expressed active caspase- 3 in all three regions of untreated BPs. Some hair cells with active caspase-3 near the luminal surface of the sensory epithelium have lost their Tuj1 antigenicity (arrowheads). D-

class 3 B-tubulin (Tuj1) in order to label hair cell cytoplasm (Stone et al. 1996).

Active caspase-3. Untreated control BPs contained few hair cells with active caspase-3 (Tuj1+/AC3+), scattered in the apical, middle, and basal thirds of the BP (Fig. 5A-C). In comparison to controls $(6 \mathrm{~h}, n=6$; $12 \mathrm{~h}, n=9)$, gentamicin-treated BPs showed a robust increase in Tuj1+/AC3+ cells in all three segments (apical, middle, basal) at both $6(n=5$, data not shown) and $12 \mathrm{~h}$ of gentamicin exposure $(n=9$, Fig. $5 \mathrm{D}-\mathrm{F})$.

Occasional cells in the control tissues were labeled for active caspase-3 but not Tuj1 (Tuj1-/AC3+) (Fig. 5B-C). These cells (Tuj1-/AC3+) were interpreted as hair cells because they had sizes and shapes similar to adjacent Tuj1-positive hair cells and were located within $10 \mu \mathrm{m}$ of the luminal surface of the SE. Supporting cells were easily distinguishable from hair cells by their deeper location within the SE. Unlike the Tuj1+/AC3+ cells at these two time-points, almost
F. Gentamicin-treated BPs; after exposure to $0.5 \mathrm{mM}$ gentamicin for $12 \mathrm{~h}$, many hair cells remaining in the sensory epithelium showed immunostaining for active caspase-3 (Tuj1+/AC3+). Its expression was noted throughout the apical, middle, and basal regions with no apparent gradient (arrows). In the basal third, a large number of Tuj1negative hair cells expressed active caspase-3 as well (Tuj1-/AC3+; arrowheads). Scale bar $=20 \mu \mathrm{m}$.

all of the Tuj1-/AC3+ cells were distributed in the basal third in both control and gentamicin-damaged BPs. Figure 6 summarizes the cell counts for both control cultures and BPs cultured in the presence of gentamicin. Note that many more cells showed active caspase-3 labeling after $12 \mathrm{~h}$ than after $6 \mathrm{~h}$ of gentamicin exposure (note scale difference on ordinates of Fig. $6 \mathrm{~A}$ and $\mathrm{B}$ ). After $6 \mathrm{~h}$ of gentamicin treatment, the average numbers of both Tuj1+/AC3+ $(p<0.001)$ and Tuj1-/AC3+ $(p<0.05)$ cells were increased significantly compared with controls. By $12 \mathrm{~h}$, the counts of Tuj1+/AC3+ and Tuj1-/AC3+ cells remained low in the untreated organs. Again, gentamicin significantly increased both the Tuj1+/AC3+ $(p<0.001)$ and Tuj1-/AC3+ $(p<0.01)$ cells at this time-point.

Active caspase-8 and caspase-9. Immunolabeling for active caspase-9 was performed on BPs treated with gentamicin for 6 or $12 \mathrm{~h}$ and their respective controls. Representative micrographs from control (Fig. 7A-C) and 12-h gentamicin-treated BPs (Fig. 7D-F) are 

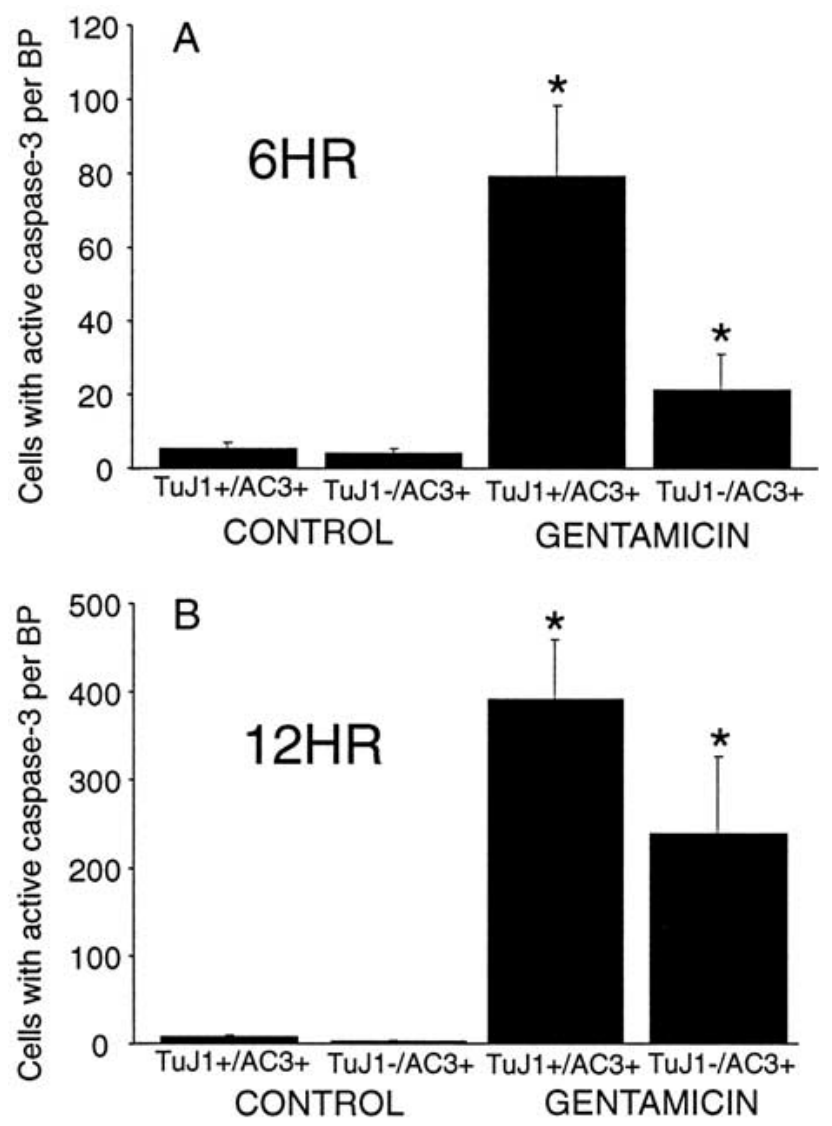

FIG. 6. Cell counts of active caspase- 3 expression in control and gentamicin-treated basilar papillae (BP). Cells double-labeled for Tuj 1 and active caspase-3 (Tuj1+/AC $3+$ ) and Tuj1-negative cells expressing active caspase-3 (Tuj1-/AC3+) near the luminal surface of the sensory epithelium were counted in each gentamicin-treated and parallel control BP. A. A 6-h treatment with gentamicin significantly promoted active caspase-3 expression in both Tuj1-positive $(p<$ $0.001)$ and Tuj1-negative $(p<0.05)$ hair cells in comparison to controls. B. By $12 \mathrm{~h}$ of gentamicin exposure, these differences have further widened. Significantly more Tuj1-positive $(p<0.001)$ and Tuj1-negative $(p<0.01)$ cells expressed active caspase-3 compared with controls, ( $n^{\prime}$ s: control $6 \mathrm{~h}, n=6$; control $12 \mathrm{~h}, n=9$; gent $6 \mathrm{~h}$, $n=5$; gent $12 \mathrm{~h}, n=9$ ). Error bars = SEM.

shown. Fewer hair cells were labeled for active caspase-9 (Tuj1+/AC9+) in control tissues in comparison to those treated with gentamicin for $6(n=5)$ or $12 \mathrm{~h}(n=7)$. Tuj1-/AC9+ cells were rarely observed in control or gentamicin-damaged BPs at either timepoint. Cell counts are shown in Figure 8. In both the 6-h $(n=6)$ and 12-h $(n=5)$ control groups, the total number of hair cells expressing active caspase-9 averaged fewer than 30 per BP. Exposure to gentamicin for $6 \mathrm{~h}$ significantly increased the number of the Tuj1+/AC9+ $(p<0.001)$ but not that of Tuj1-/AC9+ cells. At $12 \mathrm{~h}$, gentamicin-treated BPs again contained significantly more Tuj1+/AC9+ cells than control BPs $(p<0.001)$, with the number of Tuj1-/AC9+ remaining low and similar to that of the controls. When comparing the counts of AC9+ to AC3+ hair cells, we have observed significantly more Tuj1-/AC3+ cells than Tuj1-/AC9+ cells after gentamicin treatment for $6(p<0.01)$ or $12 \mathrm{~h}(p<0.01)$.

Three antibodies against cleaved caspase-8 (BD Pharmingen; Cell Signaling; SmithKline Beecham, King of Prussia, PA) were tested in control or gentamicin-treated tissues. At several concentrations these antibodies produced either high background or no apparent cellular staining. Despite reliable labeling in positive controls using mouse tissues, they were unable to stain positive controls using chick cochleae treated with staurosporine, a known cell-death-inducing agent. These antibodies are likely inappropriate for immunohistochemistry in chicken tissues.

\section{Detection of caspase activity with fluorogenic substrates}

In addition to immunohistochemical identification, caspase activity was assessed by observing substrate activation in live cultures. Hence we examined nonspecific caspase binding as well as binding to substrates thought to be relatively specific for the activated caspase- 3 , activated caspase- 8 , and activated caspase-9 (Thornberry et al. 1997; Garcia-Calvo et al. 1998).

The fam-VAD-fmk fluorogenic substrate was used to detect general caspase activity (data not shown). After $12 \mathrm{~h}$ there was noticeably more general caspase activity in the gentamicin-treated $(0.5 \mathrm{mM}, n=4)$ than control tissues $(n=4)$. This difference was seen in the apical, middle, and basal thirds of all samples tested. Thus, we proceeded to examine the activation of specific caspases.

Caspase-3 activity was assessed in damaged and control BPs using the fluorescent substrate famDEVD-fmk. Figure 9 shows representative images selected from control (Fig. 9A-C, $n=8$ ) as well as gentamicin-treated BPs (Fig. 9D-F, $0.5 \mathrm{mM}$ gentamicin, $n=8$ ). Very few hair cells (phalloidin-labeled) with caspase- 3 activity were present in the control BPs. This contrasts greatly with BPs damaged with gentamicin for $12 \mathrm{~h}$. Apical, middle, and basal thirds from gentamicin-treated BPs typically contained substantial caspase- 3 activity with this assay as well. The middle and basal thirds showed greater labeling than the apex.

Using fam-LETD-fmk and fam-LEHD-fmk fluorogenic substrates, we also found more caspase- 8 (Fig. 10D-F, $n=8$ ) and caspase-9 (Fig. 11D-F, $n=12$ ) activities in gentamicin-damaged $(0.5 \mathrm{mM}$ for $12 \mathrm{~h})$ than respective control tissues (Fig. 10A-C, $n=8$; Fig. $10 \mathrm{~A}-\mathrm{C}, n=12)$. Substantial activation of caspase- 8 and caspase-9 was evident in the apical, middle, and basal segments of the gentamicin-damaged BPs. The 

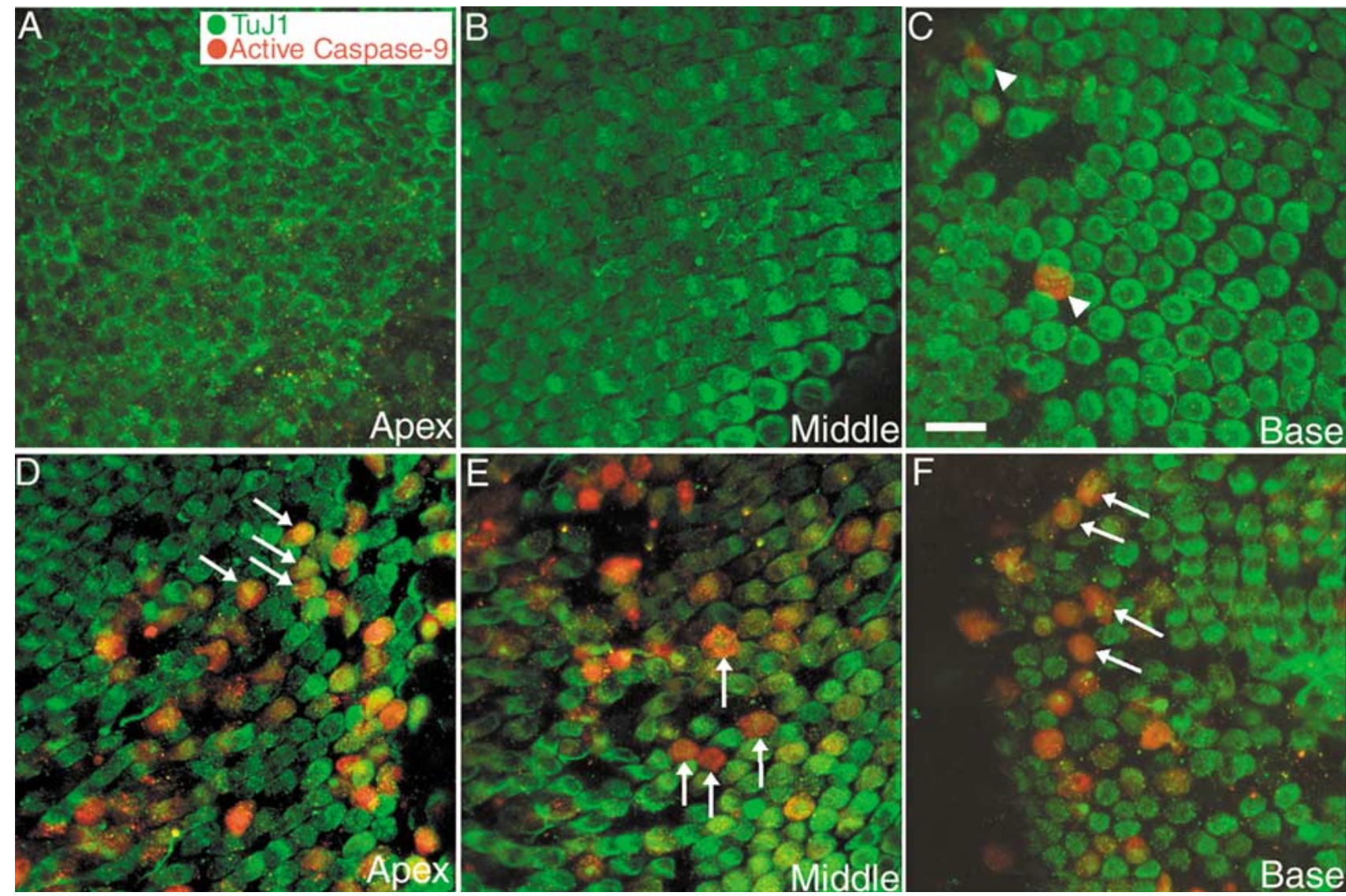

FIG. 7. Activation of caspase-9 in untreated and gentamicin-treated auditory hair cells. Whole organ basilar papillae (BP) were treated with $0.5 \mathrm{mM}$ gentamicin for $12 \mathrm{~h}$ and tested alongside untreated controls. These tissues were then fixed and processed for immunohistochemistry for Tuj1 (green) and active caspase-9 (red). A-C.

majority of the hair cells with active caspase- 8 or active caspase-9 were distributed near the junction of the basal and middle thirds of the BP, similar to the pattern seen with caspase- 3 activation.

\section{DISCUSSION}

Despite extensive literature on the loss of sensory hair cells as a result of aminoglycoside exposure, the cellular cascades determining hair cell death or survival remain unclear. Several lines of independent research have recently described the involvement of caspases in hair cell degeneration (Liu et al. 1998; Forge and Li 2000; Matsui et al. 2002). We were able to extend these findings to a mature avian auditory receptor epithelium using fam-VAD-fmk substrate to show enhanced caspase (general) activity in gentamicin-treated hair cells. Using z-VAD-fmk, a broadspectrum caspase inhibitor, we were able to protect hair cells against gentamicin-induced death. These results further support the hypothesis that activated
Control BPs; without antibiotic exposure, very few caspase-9-positive cells (arrowheads) were observed. D-F. Gentamicin-treated BPs; hair cells from gentamicin-treated BPs show robust expression of active caspase- 9 in the apical, middle, and basal regions (Tuj1+/ AC9+; arrows). Scale bar $=20 \mu \mathrm{m}$.

caspases are key mediators of aminoglycoside-induced hair cell death. It is important to point out that caspase inhibition did not completely block gentamicin-induced hair cell death, and that, despite caspase inhibition, hair cell survival decreased when the exposure to gentamicin was extended from 12 to 24 $\mathrm{h}$. This suggests that caspase-independent mechanisms may also mediate hair cell death; a similar phenomenon has been previously reported in the inner ear (Cheng et al. 1999) and other systems (Miller et al. 1997; Samejima et al. 1998; Stefanis et al. 1999). Although more sustained (3-6 days) protection has been reported with caspase inhibition in vestibular hair cells, this protection was also incomplete (Forge and Li 2000; Matsui et al. 2002).

Investigators have suggested that differences in susceptibility of apical versus basal hair cells in mammals may depend on intrinsic antioxidant levels (Sha et al. 2001). Although our in vitro preparation of chick BP shows this difference in susceptibility, our subsequent investigations of caspase activation did not expressly address this issue. It is noteworthy, 

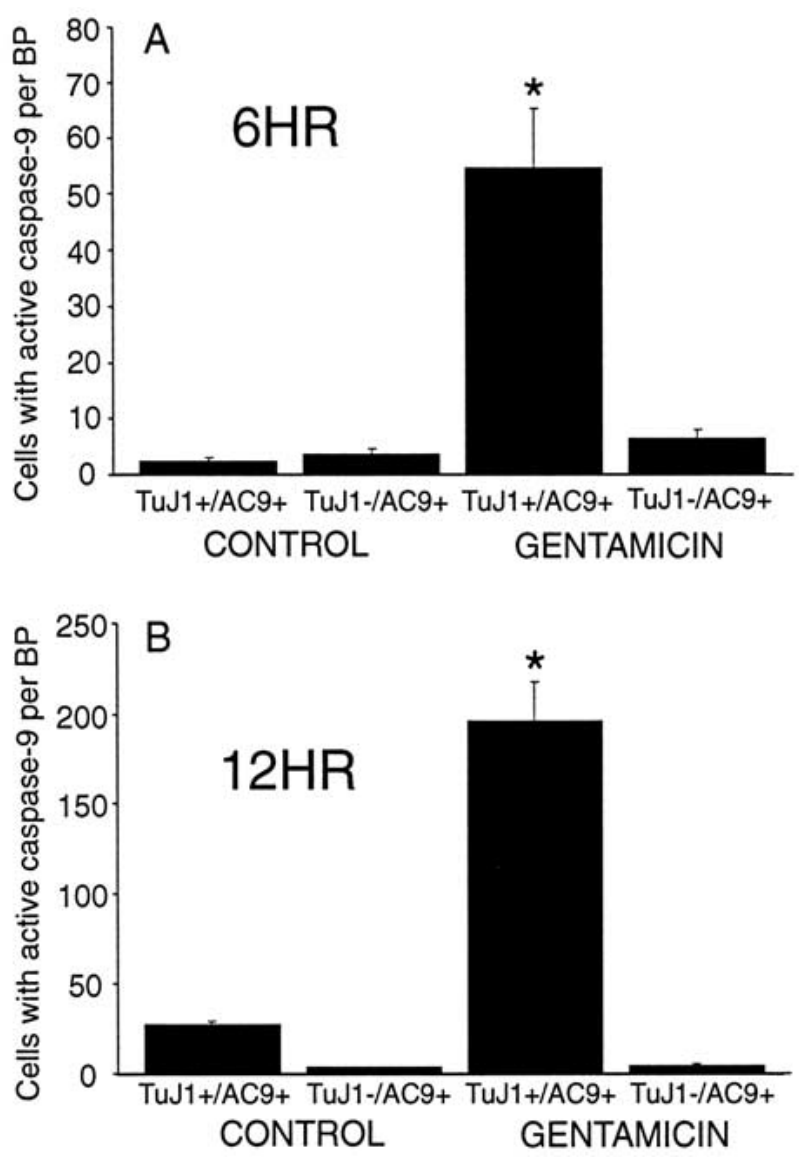

FIG. 8. Quantification of hair cells expressing active caspase-9 in undamaged and gentamicin-damaged basilar papillae (BP). Organotypic cultures were exposed to no or $0.5 \mathrm{mM}$ gentamicin for 6 or 12 h ( $n^{\prime}$ s: control $6 \mathrm{~h}, n=6$; control $12 \mathrm{~h}, n=5$; gent $6 \mathrm{~h}, n=5$; gent 12 h, $n=7)$. A. Significantly more Tuj1-positive (Tuj1+) hair cells expressed active caspase- 9 (AC9+) after $6 \mathrm{~h}$ of gentamicin treatment in comparison to controls $(p<0.001)$. B. The number of Tuj1+/AC9+ cells remained significantly higher than controls in BPs treated with gentamicin for $12 \mathrm{~h}(p<0.001)$. Unlike active caspase-3 expression, active caspase- 9 was rarely seen in association with Tuj1-negative hair cells under any treatment paradigms tested. Error bars = SEM.

however, that similar patterns of caspase-3, caspase-8, and caspase- 9 activation were seen in the basal, middle, and apical regions of the BP at an aminoglycoside level that causes hair cell loss in all three regions. These findings suggest that hair cells with different levels of sensitivity have similar cell death mediators.

Only a subset of the 14 known mammalian caspases functions as cell death mediators. These fall into two general categories: initiators and effectors (see reviews: Earnshaw et al. 1999; Nicholson 1999; Hengartner 2000). Initiator caspases include caspase-8 and caspase-9, while effector caspases include caspase-3, caspase-6, and caspase-7. Other caspase members function to process cytokines (caspase-1, caspase-4, caspase-5, caspase-11, and caspase-13), mediate damage directed at the endoplasmic reticulum (caspase-12), act as a tissue-specific positive or negative cell death regulator (caspase-2), or have unknown functions (caspase-10 and caspase-14). Upstream initiator caspases are activated in response to specific cell death triggers. The specific upstream caspase that is activated corresponds to the subcellular site of damage. Activation of certain cell surface death receptors will result in activation of caspase-8, whereas caspase-9 is preferentially activated by cellular stresses targeting the mitochondria (Earnshaw et al. 1999; Hengartner 2000; Krammer 2000). Once activated, these upstream caspases can cleave and activate downstream effector caspases, thus forming a caspase cascade. We have begun to look for the activation of specific caspases in degenerating hair cells of the chick BP.

Significantly more immunologic expression is demonstrated for both active caspase-3 and active caspase-9 in gentamicin-treated hair cells than controls cultured for the same duration. Using caspase substrates to detect active caspase- 3 and active caspase-9, we correlated the increased immunoreactivity with their actual activities in situ in response to gentamicin treatment. Thus, the two methods used to detect activation of specific caspases were in agreement. In comparison to immunodetection, the substrate activation assay appears to be more sensitive but less specific. Like specific caspase inhibitors, the substrates can potentially bind other individual caspases with much lower affinity (Thornberry et al. 1997; Garcia-Calvo et al. 1998; reviewed in Stennicke and Salvesen 1999). In addition, immunohistochemistry examines tissues at a single time-point, whereas caspase substrate in our experiment was exposed to active caspase within live tissues for $1 \mathrm{~h}$.

Our data strongly implicate the activation of caspase- 9 as one of the key events mediating gentamicininduced hair cell degeneration. Cellular stresses that result in depletion of cellular metabolic energy such as reactive oxygen species (ROS) are associated with activation of caspase- 9 via the binding of apoptotic protease activating factor (Apaf-1) and cytochrome c released by the mitochondria (Earnshaw et al. 1999; Hengartner 2000). Generation of ROS and calcium dysregulation are known to occur in auditory hair cells damaged by gentamicin in vivo and in vitro (reviewed in Rybak 1996; Hirose et al. 1997, 1999; Sha and Schacht 1999; reviewed in Forge and Schacht 2000). Three additional observations support the concept that mitochondria play a key role in mediating aminoglycoside ototoxicity. First, patients with mutations of the mitochondrial ribosomal RNA are predisposed to aminoglycoside-induced hearing loss (Prezant et al. 1993; Estivill et al. 1997; Casano et al. 1999). Second, concurrent addition of chloramphenicol, a specific mitochondrial poison, has been shown to increase the extent of gentamicin-induced 

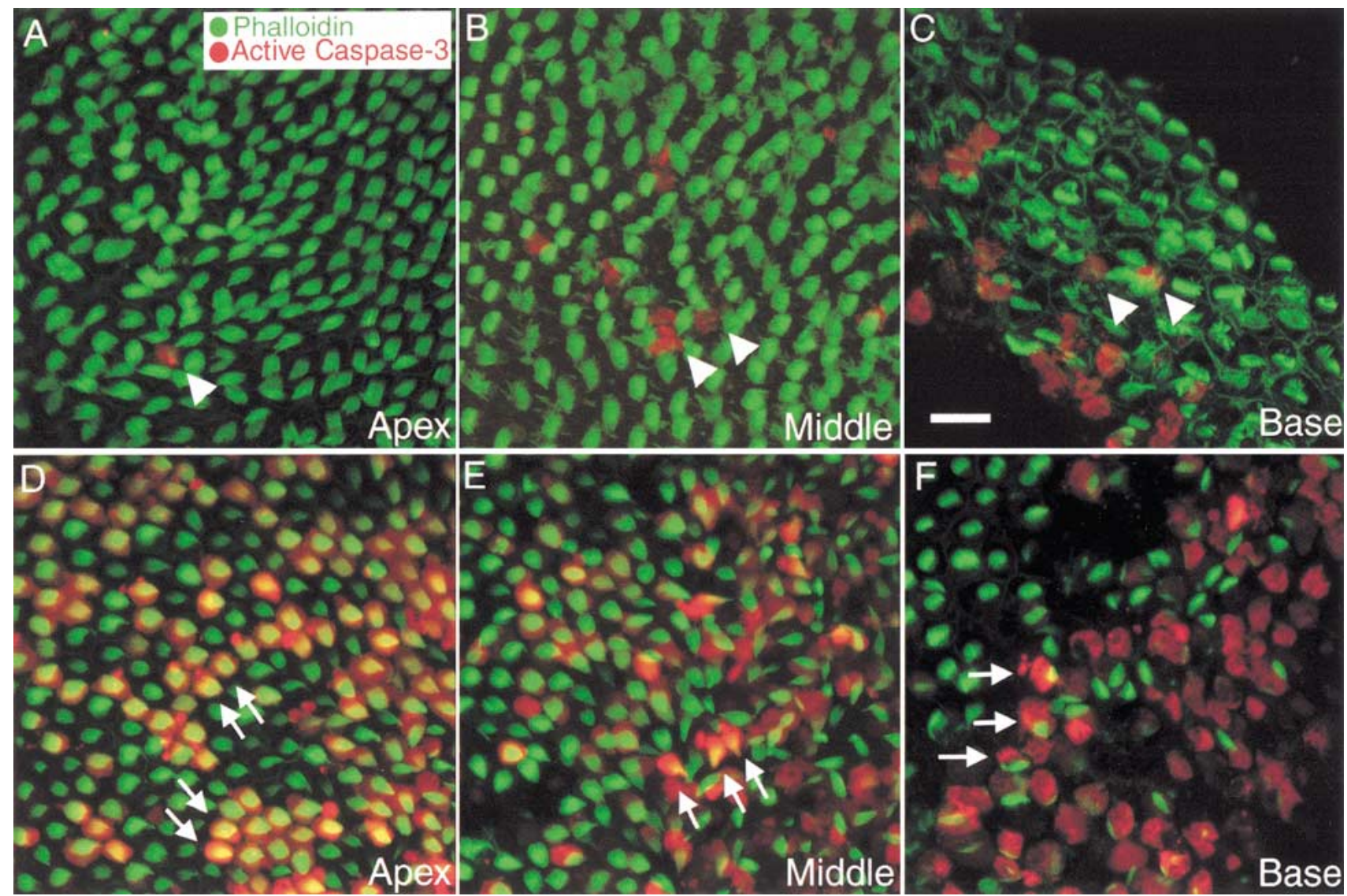

FIG. 9. Confocal images of active caspase-3 detected with a fluorescent-conjugated substrate. Basilar papillae (BP) were incubated in media supplemented with no or $0.5 \mathrm{mM}$ gentamicin for $12 \mathrm{~h}$. During the last hour of this culture period, fam-DEVD-fmk was added to specifically detect the presence of active caspase-3 (red) in these tissues, which were then fixed and stained with phalloidin (green) to label hair cell stereocilia. A-C. Control BPs; very few scattered hair

hair cell loss in vivo (Hyde and Rubel 1995). Third, we have observed a caspase-independent translocation of cytochrome $\mathrm{c}$ from the mitochondria to the cytoplasm during gentamicin-induced hair cell degeneration in vitro (Cheng et al. 2002). Since numerous pro-apoptotic (e.g., bax, bid) and antiapoptotic (e.g., bcl-2, bcl- $\mathrm{X}_{\mathrm{L}}$ ) signals converge at this organelle, the mitochondrion is thought to act as a central checkpoint for the apoptotic machinery in several systems (Earnshaw et al. 1999; Slee et al. 1999a; Hengartner 2000). Our observation of significant activation of caspase-9 with gentamicin exposure is in agreement with these lines of evidence.

Thus far we have examined only one effector caspase, caspase-3. Features of apoptosis such as nuclear condensation and DNA fragmentation are mediated by the activity of caspase-3 (Woo et al. 1998; D'Mello et al. 2000), and several studies have reported such changes in gentamicin-treated hair cells ( $\mathrm{Li}$ et al. 1995; Lang and Liu 1997; Zheng et al. 1999; Forge and Li 2000). Liu et al. (1998) showed that in vitro cells with active caspase- 3 were demonstrated along the control BPs (arrowheads). D-F. Gentamicin-treated BPs; there was robust expression of active caspase- 3 in hair cells from the apical, middle, and basal segments. Arrows point to examples of double-labeled cells. Despite considerable hair cell loss at this time-point, many of the remaining hair cells expressed active caspase-3. Scale bar $=20 \mu \mathrm{m}$.

application of a specific inhibitor of caspase-3 prevented cisplatin-induced hair cell death and reduced TUNEL labeling. Our data indicate that gentamicintreated hair cells strongly express active caspase-3. Interestingly, we also observed significantly more Tuj1-/AC3+ cells than Tuj1-/AC9+ cells after gentamicin treatment for 6 or $12 \mathrm{~h}$. A reasonable explanation for this observation is that the loss of Tuj1 antigenicity is a late event during hair cell degeneration. Therefore, we can speculate that the activation of caspase- 3 occurs later than caspase- 9 activation, coinciding approximately with the time when antigenicity of Tuj1 is lost. While our experiments do not provide direct evidence that the initiator caspase- 9 is activated prior to caspase- 3 activation, this proposed sequence of caspase activation corresponds to that described in the literature in other systems (Slee et al. 1999a,b; Hengartner 2000).

Although we were unable to find any immunologic evidence of active caspase- 8 , its potential role in mediating hair cell death cannot be ruled out. The 

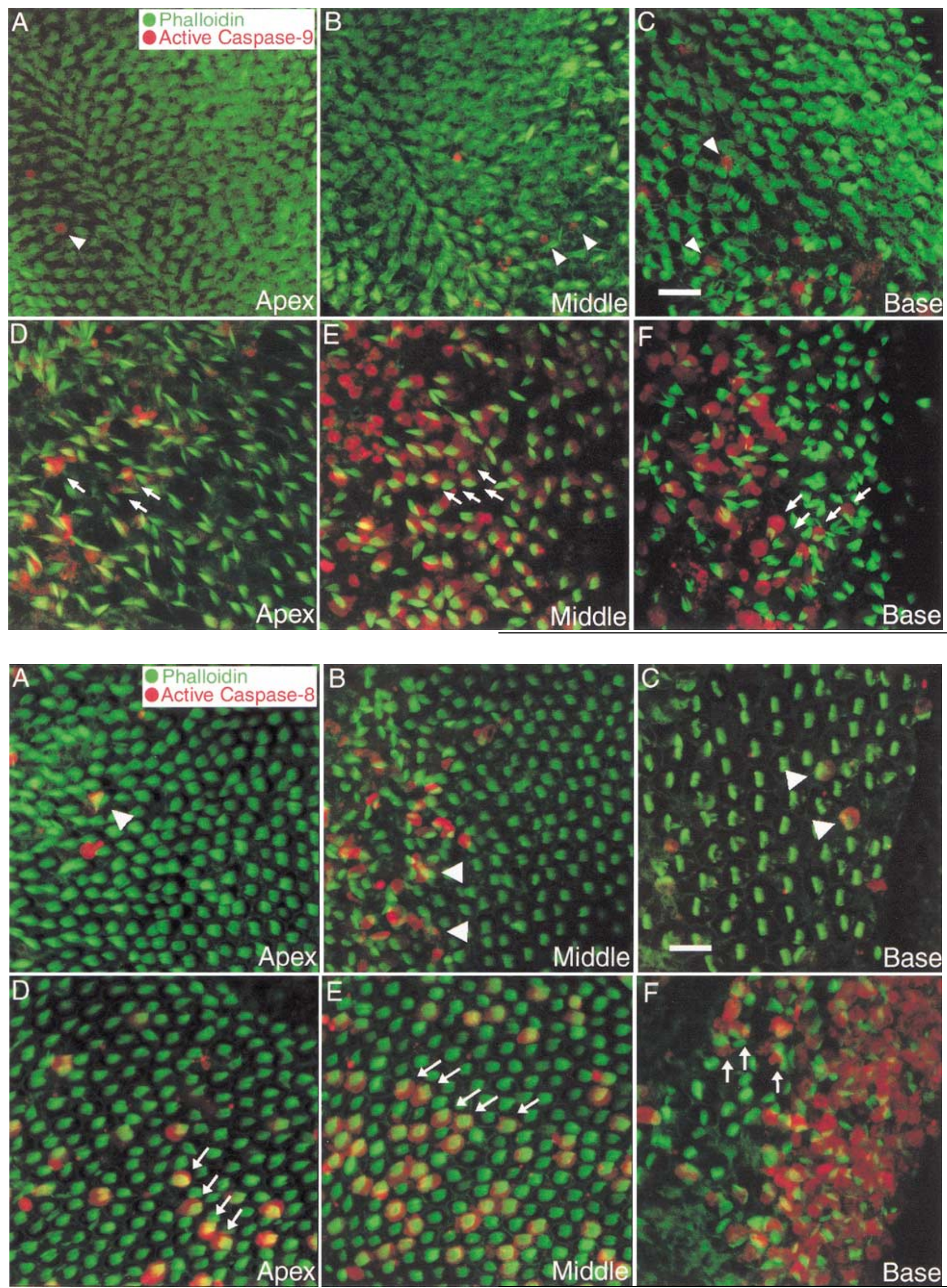

F

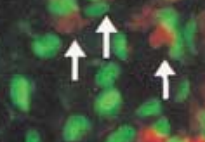


FIG. 10. Detection of active caspase- 9 in control and gentamicintreated basilar papillae (BP) using fluorescent-labeled substrates. Confocal images. A subset of the BP cultures was treated with 0.5 $\mathrm{mM}$ gentamicin for $12 \mathrm{~h}$ before fam-LEHD-fmk, a peptide that specifically binds to active caspase-9 (red), was added. All tissues were then fixed and stained with phalloidin (green). A-C. Control BPs; healthy sheets of hair cells with little active caspase-9 labeling (arrowheads) were noted along the BP. D-F. Gentamicin-treated BPs; gentamicin treatment decreased the hair cell density and increased the expression of active caspase- 9 in hair cells throughout the BP. Arrows indicate examples of double-labeled cells. The majority of active caspase- 9 expression was observed near the junction of the middle and basal regions. Scale bar $=20 \mu \mathrm{m}$.

FIG. 11. Active caspase-8 expression in untreated and gentamicintreated basilar papillae (BP). Confocal images. After exposure to no or $0.5 \mathrm{mM}$ gentamicin for $11 \mathrm{~h}$, BP cultures received fam-LETD-fmk to specifically detect the activity of active caspase- 8 (red). Fluorescent-conjugated phalloidin was used to label hair cells (green). A-C. Control BPs; apical, middle, basal regions of untreated BPs contained many hair cells but few labeled with active caspase-8 (arrowheads). D-F. Gentamicin-treated BPs; gentamicin treatment promoted the activation of caspase- 8 in many hair cells throughout the BP. Arrows point to examples of double-labeled cells. There are occasional phalloidin-negative cells expressing active caspase-8 noted near the luminal surface of the sensory epithelium. Similar to the expression of active caspase- 3 and active caspase- 9 , many of the hair cells showing active caspase- 8 are concentrated in the middle and basal thirds of the BP. Scale bar $=20 \mu \mathrm{m}$.

finding that caspase-1 inhibitor protected against cisplatin-induced hair cell death (Liu et al. 1998) supports a role for the death receptor pathway during hair cell degeneration. Although caspase-1 is primarily known to mediate inflammatory responses, caspase-1-deficient cells have been reported to be more resistant to cell death stimulated by the death receptor pathway (Earnshaw et al. 1999). Pro-caspase8 is closely associated with membrane-bound receptors carrying so-called death domains, a model well characterized in the immune system (Slee et al. 1999a; Hengartner 2000; Krammer 2000). Upon activation of these receptors by TNFA or Fas (both paracrines secreted by inflammatory cells), pro-caspase- 8 molecules are attracted to and cluster at the receptor level to allow for autocleavage and thus activation. Macrophages and other as-yet-unspecified inflammatory cells normally reside within the auditory SE (Warchol 1997; Bhave et al. 1998). Within hours of aminoglycoside exposure, their numbers increase, especially in areas of hair cell lesions (Warchol 1997; Bhave et al. 1998). Although their precise function(s) within the sensory organ remains unclear, these inflammatory cells may potentially promote hair cell degeneration by releasing TNFA, Fas, or other death receptor ligands.
Whether or not the mitochondrial or the death receptor pathway plays a more important role during aminoglycoside-induced hair cell degeneration remains to be determined. Future experiments using specific inhibitors of caspase- 8 or caspase- 9 will further clarify the roles of these pathways during hair cell death and the relationships between the initiator and effector caspases.

\section{Technical considerations}

Studies on hair cell damage in nonavian systems have shown that loss of the apical stereocilia can precede hair cell death (Sobkowicz et al. 1992; Zheng et al. 1999; Gale et al. 2002). We considered this complication and carried out experiments to compare loss of phalloidin with loss of Tuj1 antigenicity. In the gentamicin-treated chick BPs, we show phalloidin to be an accurate hair cell marker of surviving hair cells. The population of Tuj1-positive, phalloidin-negative cells was estimated to be less than $0.5 \%$ of all the remaining hair cells. This interpretation, of course, depends on the assumption that the disappearance of Tuj1 antigenicity is a late degenerative event.

The observed basal-apical gradient of hair cell loss in chick BP is consistent with previous in vivo (Cruz et al. 1987; Tucci and Rubel 1990; Janas et al. 1995, Torchinsky et al. 1999) and in vitro reports (Frenz et al. 1998). With respect to both the temporal pattern and gentamicin concentration, hair cells degenerated in a basal-apical fashion. Hair cell death in the apical third is seldom seen with in vivo application of aminoglycosides. Our findings of hair cell death in these regions are in agreement with those reported in the literature for in vitro preparations as well (Hirose et al. 1997; Frenz et al. 1998).

\section{ACKNOWLEDGMENTS}

We thank Dr. Sarah Woolley for assistance with data analysis, Laurie Johnson for help with preparation of the manuscript, Glen MacDonald, Dr. Jialin Shang, and Mae del Puerto for their excellent technical support. This work was supported by NIDCD grants DC-00018 and DC-00054 and the American Academy of Otolaryngology-Head and Neck Surgery Resident Research Grant.

\section{REFERENCES}

Bedner E, Smolewski P, Amstad P, Darzynkiewicz Z. Activation of caspases measured in situ by binding of fluorochrome-labeled inhibitors of caspases (FLICA): correlation with DNA fragmentation. Exp. Cell Res. 259:308-313, 2000.

Bhave SA, Oesterle EC, Coltrera MD. Macrophage and microglialike cells in the avian inner ear. J. Comp. Neurol. 398:241-256, 1998. 
Casano RA, Johnson DF, Bykhovskaya Y, Torricelli F, Bigozzi M, Fischel-GHODSIAN N. Inherited susceptibility to aminoglycoside ototoxicity: genetic heterogeneity and clinical implications. Am. J. Otolaryngol 20:151-156, 1999.

Casiano CA, Martin SJ, Green DR, Tan EM. Selective cleavage of nuclear autoantigens during CD95 Fas/APO-1-mediated T cell apoptosis. J. Exp. Med. 184:765-770, 1996.

Cheng AG, Cunningham LL, Rubel EW. Translocation of cytochrome $\mathrm{c}$ in hair cells of gentamicin-treated avian basilar papilla. Abstr. Assoc. Res. Otolaryngol. 25:35, 2002.

Cheng Ag, Huang T, Stracher A, Kim A, Liu W, Malgrange B, Lefebvre PP, Schulman A, Van De Water TR. Calpain inhibitors protect auditory sensory cells from hypoxia and neurotrophin-withdrawal induced apoptosis. Brain Res. 850:234-243, 1999.

Clarke PG, Clarke S. Historic apoptosis. Nature 378:230, 1995.

Clem RJ, Cheng EH, Karp CL, Kirsch DG, Ueno K, Takashi A, Katan MB, Griffin DE, Earnshaw WC, Veliuona MA, Hardwick JM. Modulation of cell death by bcl- $\mathrm{X}_{\mathrm{L}}$ through caspase interaction. Proc. Natl. Acad. Sci. USA 95:554-559, 1998.

CRUZ RM, LAMBERT PR, RUBEL EW. Light microscopic evidence of hair cell regeneration after gentamicin toxicity in chick cochlea. Arch. Otolaryngol. Head Neck Surg. 113:1058-1062, 1987.

Cunningham LL, Cheng AG, Rubel EW. Caspase activation in hair cells of the mouse utricles exposed to neomycin. J. Neurosci. 2002 in press.

D'Mello SR, Kuan C-Y, Flavell RA, Rakic P. Caspase-3 is required for apoptosis-associated DNA fragmentation but not for cell death in neurons deprived of potassium. J. Neurosci. Res. 59:24-31, 2000.

Earnshaw WC, Martins LM, Kaufmann SH. Mammalian caspases: structure, activation, substrates, and functions during apoptosis. Annu. Rev. Biochem. 68:383-424, 1999.

Enari M, Sakahira H, Yokoyama H, Okawa K, Iwamatsu A, Nagata S. A caspase-activated DNase that degrades DNA during apoptosis, and its inhibitor ICAD [see comments]. Nature 391:43-50, 1998.

Estivill X, Govea N, Barceló A, Perelló E, Badenas C, Romero E, Moral L, Scozzari R, D'Urbano L, Zeviani M, Torroni A. Familial progressive sensorineural deafness is mainly due to the mtDNA A1555G mutation and is enhanced by the treatment of aminoglycosides. Am. J. Hum. Genet. 62:27-35, 1997.

ForGE A. Outer hair cell loss and supporting cell expansion following chronic gentamicin treatment. Hear. Res. 19:171-182, 1985.

Forge A, Li L. Apoptotic death of hair cells in mammalian vestibular sensory epithelia. Hear. Res. 139:97-115, 2000.

Forge A, SCHACHT J. Aminoglycoside antibiotics. Audiol. Neurootol. 5:3-22, 2000.

Frenz DA, Yoo H, Liu W. Basilar papilla explants: a model to study hair cell regeneration-repair and protection. Acta Otolaryngol. 118:651-659, 1998.

Gale JE, Meyers JR, Periasamy A, Corwin JT. Survival of bundleless hair cells and subsequent bundle replacement in the bullfrog's saccule. J. Neurobiol. 50:81-92, 2002.

Garcia-Calvo M, Peterson EP, Leiting B, Ruel R, Nicholson DW, THORNBERRY NA. Inhibition of human caspases by peptide-based and macromolecular inhibitors. J. Biol. Chem. 273:3260832613, 1998.

Gavrieli Y, Sherman Y, Ben-Sasson SA. Identification of programmed cell death in situ via specific labeling of nuclear DNA fragmentation. J. Cell. Biol. 119:493-501, 1992.

Hengartner MO. The biochemistry of apoptosis. Nature 407:770$776,2000$.

Hirose K, Hockenbery DM, Rubel EW. Reactive oxygen species in chick hair cells after gentamicin exposure in vitro. Hear. Res. 104:1-14, 1997.
Hirose K, Westrum Le, Stone JS, Zirpel L, Rubel EW. Dynamic studies of ototoxicity in mature avian auditory epithelium. Ann. N. Y. Acad. Sci. 884:389-409, 1999

Hu BH, Guo W, Wang PY, Henderson D, Jiang SC. Intense noiseinduced apoptosis in hair cells of guinea pig cochleae. Acta Otolaryngol. 120:19-24, 2000.

Hyde GE, RubEL EW. Mitochondrial role in hair cell survival after injury. Otolaryngol. Head Neck Surg. 113:530-540, 1995.

Janas JD, Cotanche DA, Rubel EW. Avian cochlear hair cell regeneration: stereological analyses of damage and recovery from a single high dose of gentamicin. Hear. Res. 92:17-29, 1995.

Janicke RU, Ng P, Sprengart ML, Porter AG. Caspase-3 is required for alpha-fodrin cleavage but dispensable for cleavage of other death substrates in apoptosis. J. Biol. Chem. 273:15540-15545, 1998.

Kerr JF, Wyllie AH, Currie AR. Apoptosis: a basic biological phenomenon with wide-ranging implications in tissue kinetics. Br. J. Cancer 26:239-257, 1972.

KIL J, Warchol ME, Corwin JT. Cell death, cell proliferation, and estimates of hair cell life spans in the vestibular organs of chicks. Hear. Res. 114:117-126, 1997.

KrAMMER PH. CD95 is deadly mission in the immune system. Nature 407:789-795, 2000.

Lang H, Liu C. Apoptosis and hair cell degeneration in the vestibular sensory epithelia of the guinea pig following a gentamicin insult. Hear. Res. 111:177-184, 1997.

Lazebnik YA, Takahashi A, Moir RD, Goldman RD, Poirier GG, Kaufmann SH, Earnshaw WC. Studies of the lamin proteinase reveal multiple parallel biochemical pathways during apoptotic execution. Proc. Natl. Acad Sci. USA 92:9042-9046, 1995.

Lenoir M, Daude N, Humbert G, Renard N, Gallego M, Pujol R, Eybalin M, VAGO P. Morphological and molecular changes in the inner hair cell region of the rat cochlea after amikacin treatment. J. Neurocytol. 28:925-937, 1999.

Li L, Nevill G, Forge A. Two modes of hair cell loss from the vestibular sensory epithelia of the guinea pig inner ear. J. Comp. Neurol. 355:405-417, 1995.

Liu W, Staecker H, Stupak H, Malgrange B, Lefebvre P, Van De WATER TR. Caspase inhibitors prevent cisplatin-induced apoptosis of auditory sensory cells. Neuroreport 9:2609-2614, 1998.

Mashima T, Naito M, Fujita N, Noguchi K, Tsuruo T. Identification of actin as a substrate of ICE and an ICE-like protease and involvement of an ICE-like protease but not ICE in VP-16-induced U937 apoptosis. Biochem. Biophys. Res. Commun. 217:1185-1192, 1995.

Mashima T, Naito M, Noguchi K, Miller DK, Nicholson DW, Tsuruo T. Actin cleavage by CPP-32/apopain during the development of apoptosis. Oncogene 14:1007-1012, 1997.

Matsui JI, Ogilvie JM, Warchol ME. Inhibition of caspases prevents ototoxic and ongoing hair cell death. J. Neurosci. 22:1218-1227, 2002

Miller TM, Moulder KL, Knudson CM, Creedon DJ, Deshmukh M, KorSmeyer SJ, Johnson JR EM. Bax deletion further orders the cell death pathway in cerebellar granule cells and suggests a caspase-independent pathway to cell death. J. Cell. Biol. 139:205-217, 1997.

Nicholson DW. Caspase structure, proteolytic substrates, and function during apoptotic cell death. Cell Death Differ. 6:10281042, 1999.

Oesterle EC, Tsue TT, Reh TA, Rubel EW. Hair-cell regeneration in organ cultures of the postnatal chicken inner ear. Hear. Res. 70:85-108, 1993

Pirvola U, Xing-Qun L, Virkkala J, Saarma M, Murakata C, Camoratto AM, Walton KM, Ylikoski J. Rescue of hearing, auditory hair cells, and neurons by CEP-1347/KT7515, an inhibitor of c-Jun N-terminal kinase activation. J. Neurosci. 20:43$50,2000$. 
Prezant TR, Agapian JV, Bohlman MC, Bu X, Oztas S, Qiu WQ, Arnos KS, Cortopassi GA, Jaber L, Rotter JI. Mitochondrial ribosomal RNA mutation associated with both antibiotic-induced and non-syndromic deafness. Nat. Genet. 4:289-294, 1993.

RуваK LP. Ototoxicity. Curr. Opin. Otolaryngol. Head Neck Surg. 4:302-307, 1996.

Samejima K, Tone S, Kottke TJ, Enari M, Sakahira H, Cooke CA, Durrieu F, Martins lM, Nagata S, Kaufmann SH, Earnshaw WC. Transition from caspase-dependent to caspase-independent mechanisms at the onset of apoptotic execution. J. Cell Biol. 143:225-239, 1998.

Sha SH, Schacht J. Stimulation of free radical formation by aminoglycoside antibiotics. Hear. Res. 128:112-118, 1999.

Sha SH, Taylor R, Forge A, SCHACHT J. Differential vulnerability of basal and apical hair cells is based on intrinsic susceptibility to free radicals. Hear. Res. 155(1-2):1-8, 2001.

Slee EA, Adrain C, Martin SJ. Serial killers: ordering caspase activation events in apoptosis. Cell Death Differ. 6:1067-1074, 1999a.

Slee EA, Harte MT, Kluck RM, Wolf BB, Casiano CA, Newmeyer DD, Wang H, Reed JC, Nicholson DW, Alnemri ES, Green DR, MARTIN SJ. Ordering the cytochrome c-initiated caspase cascade: hierarchical activation of caspases-2, $-3,-6,-7,-8$, and -10 in a caspase-9-dependent manner. J. Biol. Chem. 144:281-292, 1999b.

Sobkowicz HM, August BK, SLApnick SM. Epithelial repair following mechanical injury of the developing organ of corti in culture: an electron microscopic and autoradiographic study. Exp. Neurol. 115:44-49, 1992.

Stefanis L, Park DS, Friedman WJ, Green LA. Caspase-dependent and -independent death of camptothecin-treated embryonic cortical neurons. J. Neurosci. 19:6235-6247, 1999.

Stennicke HR, SAlvesen GS. Caspases: preparation and characterization. Methods 17:313-319, 1999.

Stone JS, LeAno SG, BAKer LP, Rubel EW. Hair cell differentiation in chick cochlear epithelium after aminoglycoside toxicity: in vivo and in vitro observations. J. Neurosci. 16:6157-6174, 1996.

TANG D, KIDD VJ. Cleavage of Dff-45/ICAD by multiple caspases is essential for its function during apoptosis. J. Biol. Chem. 273:28549-28552, 1998.
Thornberry NA, Rano TA, Rasper DM, Timkey T, Garcio-Calvo M, Houtzager VM, Nordstrom PA, Roy S, Vaillancourt JP, ChAPMAN KT, Nicholson DW. A combinatorial approach defines specificities of members of the caspase family and granzyme B. J. Biol. Chem. 272:17907-17911, 1997.

Torchinsky C, Messana EP, Arsura M, Cotanche DA. Regulation of p27Kip1 during gentamicin mediated hair cell death. J. Neurocytol. 28:913-924, 1999.

TucCi DL, Rubel EW. Physiologic status of regenerated hair cells in the avian inner ear following aminoglycoside ototoxicity. Otolaryngol. Head Neck Surg. 103:443-450, 1990.

Usami S, Takumi Y, Fujita S, Shinkawa H, Hosokawa M. Cell death in the inner ear associated with aging is apoptosis? Brain Res. 747:147-150, 1997.

WARCHOL ME. Macrophage activity in organ cultures of the avian cochlea: demonstration of a resident population and recruitment to sites of hair cell lesions. J. Neurobiol. 33:724-734, 1997.

Weisleder P, Rubel EW. Hair cell regeneration after streptomycin toxicity in the avian vestibular epithelium. J. Comp. Neurol. 331:97-110, 1993.

Williams JA, Holder N. Cell turnover in neuromasts of zebrafish larvae. Hear. Res. 143:171-181, 2000.

Woo M, Hakem R, Soengas MS, Duncan GS, Shahinian A, Kagi D, Hakem A, Mccurrach M, Khoo W, Kaufman SA, Senaldi G, Howard T, LowE SW, MaK TW. Essential contribution of caspase 3/CPP32 to apoptosis and its associated nuclear changes. Genes Dev. 12:806-819, 1998.

Yuan J, Shaham S, Ledoux S, Ellis HM, Horvitz HR. The C. elegans cell death gene ced-3 encodes a protein similar to mammalian interleukin-1 beta-converting enzyme. Cell 75:641-652, 1993.

Zheng JL, Keller G, GaO W-Q. Immunocytochemical and morphological evidence for intracellular self-repair as an important contributor to mammalian hair cell recovery. J. Neurosci. 19:2161-2170, 1999.

Zheng Y, Ikeda K, NaKamura M, Takasaka T. Endonuclease cleavage of DNA in the aged cochlea of Mongolian gerbil. Hear. Res. 126:11-18, 1998. 